\title{
FONOLOŠKA VJEŠTINA KAO DETERMINANTA DEFINIRANJA I INTERPRETACIJE FONOLOŠKOG POREMEĆAJA
}

\author{
NEDA MILOŠEVIĆ, MILE VUKOVIĆ \\ Centar za patologiju govora - Logomedica, Fakultet za specijalnu edukaciju i rehabilitaciju, Sveučilište u Beogradu, \\ neda@logomedica.rs
}

Primljeno: 11.3.2016.

Pregledni rad

Prihvaćeno: 16.9.2016.

UDK: 159.9: 81’344

Sažetak: U radu je prikazan pregled pristupa definiranju i razmatranju razvoja fonoloških vještina u cilju determiniranja i razumijevanja prirode razvojnog fonološkog poremećaja. Istaknuto je da se u ranijim radovima razvojni fonološki poremećaj spoznavao uglavnom s lingvističkog stajališta, dok je u novijoj literaturi pažnja usmjerena prema cjelokupnom jezičnom ponašanju $i$ funkcioniranju. Cilj ovog rada bio je da se na osnovu prikaza razvoja lingvističkih i psiholingvističkih teorija dade bliži konceptualni okvir fonoloških vještina i fonološkog poremećaja. Izdvojeni su ključni elementi za definiranje fonološke vještine i otkrivanje fonološkog poremećaja. Zaključeno je da poznavanje općih $i$ specifičnih karakteristika fonološkog podsustava predstavlja ključne čimbenike prepoznavanja i definiranja fonološkog poremećaja u određenom jeziku. Istovremeno je istaknuto da prisutnost razvojnog fonološkog poremé́aja predstavlja veliki rizik za pojavu teškoća u čitanju.

Ključne riječi: fonološki razvoj, fonološka vještina, fonološki poremećaj, teškoće u čitanju

\section{UVOD}

Interes za govorni glas ima dugu povijest, staru koliko i ljudska civilizacija. Mnogo je vremena proteklo od prvih spoznaja o stvaranju glasa do znanstvene određenosti fonologije kao lingvističke discipline koja pručava glasove kao govorne jedinice koje služe razlikovanju značenja. Zasluga za takvo determiniranje fonologije pripada lingvističkim istraživanjima, uz neizostavan doprinos logopedske znanosti i njenog pristupa istraživanju jezičnih poremećaja.

Različiti pristupi i teorijski modeli definiranja fonološke vještine, kao i razlike u definiranju i izdvajanju općih i pojedinačnih čimbenika značajnih za razvoj fonološke vještine, rezultirali su različitim pristupima u shvaćanju fonološkog poremećaja. Poznavanje lingvističkih i psiholingvističkih teorija u razumijevanju fonoloških vještina neophodno je za definiranje i izradu konceptulanog okvira fonološkog poremećaja. U skladu s time, cilj nam je bio da na osnovu pregleda dostupne literature doprinesemo bližem određivanju okvira fonološke vještine i razvoja fonološke strukture $\mathrm{s}$ ciljem razumijevanja i interpretacije fonološkog poremećaja.

\section{DEFINIRANJE I RAZVOJ FONOLOGIJE}

Termin fonologija uveden je u rječnik lingvistike 1923. godine, na prijedlog Ženevske škole u području koje se bavi strukturom i funkcijom glasovnog sustava jezika. Predstavnici Praške škole - Roman Jakobson i Nikolaj Sergejevič Trubeckoj, koji su svoje temelje fonologije i fonetike bazirali na istraživanjima Baudouina de Courtnaya $i$ Ferdinanda de Saussurea, fonologiju definiraju kao znanost koja proučava predodžbe glasova u ljudskoj svijesti povezane s komunikacijskom funkcijom u društvu.

Početak razvoja fonologije kao znanosti, koja je sredinom XX stoljeća doprinijela razumijevanju fonološke vještine, veže se uz formuliranje binarne teorije i teorije distinktivnih obilježja fonema koja se na njoj zasniva. Pod utjecajem de Saussureovih shvaćanja društvene funkcije jezika 
i glasa kao specifične jedinice jezičnog sustava, Trubeckoj definira fonem kao jezični znak koji služi za raspoznavanje značenja riječi, a koji se ne može zamjenjivati drugim jezičnim znacima bez posljedice po značenje. Time je Trubeckoj prvi odredio odnos fonema prema njegovim konkretnim glasovnim realizacijama, što se može vidjeti iz slijedećih primjera:

a) ako se dva glasa ne mogu međusobno zamjenjivati bez štete po značenje, onda su u pitanju realizacije dvaju posebnih fonema (npr. opozicija $k-g$ u riječima kora-gora).

b) ako dva glasa, srodna po artikulacijsko-akustičkim osobinama, ne mogu stajati $u$ istom fonetskom kontekstu, onda ih treba smatrati alofonima istog fonema (velarno $n$ u riječi Anka).

c) ako se dva glasa mogu zamjenjivati bez posljedica po značenje onda nisu u pitanju dva različita fonema već fakultativne varijante istog fonema (grleno $r$ umjesto apikalnog r). Ovim je zapažanjima Trubeckoj utro put proučavanju artikulacijsko-fonoloških poremećaja (Trubeckoj, 1949 prema Ivić, 1970).

Zaslugom teorija Jakobsona i Trubeckoja, a posebno istraživanja iz eksperimentalne fonetike, došlo se do spoznaja da su fonemi jedinice koje čini skup artikulacijskih i akustičkih osobina koje se mogu analizirati. Taj skup osobina čine distinktivna obilježja - fonološka obilježja po kojoj se jedan fonem razlikuje od drugog, odnosno po kojima dani fonem stoji u fonološkoj opoziciji prema nekom drugom fonemu. $\mathrm{Na}$ osnovu distinktivnih obilježja fonemi se svrstavaju u parove po principu binarnosti i tako stupaju u opozicije koje su binarne - u kojima se jedan član takve opozicije odlikuje prisustvom nekog/određenog distinktivnog obilježja, a drugi član odsustvom tog obilježja. Jakobson je izdvojio 12 distinktivnih obilježja fonema, za koje je smatrao da su univerzalna $u$ svim jezicima svijeta. Ova obilježja definirana su na osnovu kombinacije akustičkih i artikulacijskih osobina glasova, a čine ih: vokalnost $\sim$ nevokalnost; konsonantnost $\sim$ nekonsonantnost; kompakthost $\sim$ difuznost; napetost $\sim$ nenapetost; zvučnost $\sim$ bezvučnost; nazalnost $\sim$ oralnost; prekidnost $\sim$ neprekidnost; stridentnost $\sim$ blagost; glotalizira- nost $\sim$ neglotaliziranost ili pregradnost $\sim$ nepregradnost; $\quad$ gravisnost $\sim$ akutnost; labijaliziranost $\sim$ nelabijaliziranost; povišenost $\sim$ nepovišenost (Jakobson i Halle, 1988).

Analiza distinktivnih obilježja fonema pokazuje da je čitav fonološki sustav temeljen na opozicijama. Prema tome, kada se govori o fonemima, uz njih se uvijek može postaviti pitanje: U odnosu na što? Identitet jednog fonema otkriva se isključivo $\mathrm{u}$ odnosu na drugi fonem: što on to nema u odnosu na neki drugi fonem, što ga čini različitim? Stoga je fonološki sustav jednostavan rezultat odnosa.

Neizostavan utjecaj na razvoj fonologije imale su i Ženevska škola (Ferdinand de Saussure, Charles Bally, Albert Secheahaye), koja je stvorila korijene moderne strukturne lingvistike i Američka škola (Franz Boas, Edward Sapir, Leonard Bloomfield), koja fonem promatra kao „kompleks psiholoških asocijacija“" koje daju predodžbu glasu.

Razvojem psihologije i posebnim interesom za razvoj jezika kod djece, sredinom XX stoljeća stvara se novi pravac u znanosti, koji će kasnije iznjedriti mnoštvo modela koji se bave pojedinim aspektima jezičnog ponašanja. Tako se razvija psiholingvistički pravac istraživanja, koji proteklih desetljeća uže specijalizira svoja gledišta na pojedine aspekte jezičnog razvoja, s posebnim naglaskom na razvoj gramatike i fonologije kod djece. Zatim slijedi pretežno humanistički pravac, kojim se preko logopedskih istraživanja dopunjuje okvir razumijevanja jezičnog, a samim tim i fonološkog razvoja.

U razmatranju fonoloških vještina može se izdvojiti više teorija i modela. Osnove nativističke teorije javljaju se u strukturalističkom modelu i modelu generativne fonologije. Strukturalistički model objašnjava fonološke reprezentacije kao niz segmenata koje imaju određene fonološke osobine (Hockett, 1955). Sukladno tome razvija se ,artikulacijska“ terapija koja se isključivo fokusira na motoričku izvedbu. Generativni model, proistekao iz generativne fonološke teorije (Chomsky i Halle, 1968), predstavlja uređena pravila prema kojima od fonološke razine (jedinica leksikona) nastaje fonetska razina (ostvarenje u govoru), sa svojim distinktivnim obilježjima. Generativni pristup, koji je dominirao u ranijim razmatranjima jezičnog 
razvoja, ukazuje na to da djeca posjeduju urođenu tzv. univerzalnu gramatiku koja upravlja ili uređuje fonološke obrasce određenog jezika, koji omogućavaju učenje jezika te brzo i učinkovito stjecanje naizgled složenih jezičnih sustava (Chomsky, 1965).

Jedan od suvremenijih lingvističkih okvira koji nastoji objasniti fonološki razvoj kod djece, predstavlja teorija optimalnosti. Osnovu teorije optimalnosti nalazimo u modelu generativne gramatike, a koja ima za cilj da se u području fonologije usporede kompetencije govornika u odnosu na njegove performanse. Pružanje objašnjenja velikih razlika između kompetencija i performansi cilj je psiholingvističkih teorija (Barlow i Gierut, 1999).

Radikalno drugačiji, empirijski pristup objašnjavanju razvoja fonologije nudi model fonološkog konekcionizma, koji je proistekao iz kognitivističke teorije. Prema ovom modelu, dijete na osnovu ,ulaza“" informacija (socijalne izloženosti) ima sposobnost da usvoji čitav set jezičnog ponašanja, bez oslanjanja i pomoći urođene lingvističke strukture. Fonološki mehanizmi objašnjavaju se fiziološkim faktorima kao što su percepcija i artikulacija, ali i kognitivnim ograničenjima u učenju i obradi. Konekcionistička fonologija povezuje funkcionalni pristup s idejom o jezičnoj reprezentaciji u živčanom sustavu. Konekcionistički (neuralna mreža) pristup objašnjava kako neuralni sustav uči i predstavlja kognitivne procese (Joanisse, 2000).

Psiholingvistički model koji u cjelosti opisuje fonološke vještine, onako kako im treba pristupiti s područja smetnji i poremećaja, jest VagnerTorgesenov model sposobnosti fonološke obrade. Prema Vagner-Torgesenovom modelu, fonološka obrada predstavlja višedimenzionalnu sposobnost, koja u sebi uključuje tri nezavisne ali i korelativne komponente: fonološku svjesnost, fonološko pamćenje i brzo imenovanje (brzo prepoznavanje riječi) (Torgesen, Wagner i Rashotte, 1994; Wagner i Torgesen, 1987; Wagner i sur., 1997).

Iznesene teorije i modeli pokazuju da su fonološke vještine razmatrane s više gledišta, počevši od nativističke teorije Noama Chomskog pa do suvremenijeg, psiholingvističkog pristupa koji reprezentira Vagner-Torgesenov model vještina fonološke obrade. Dok nativistički pristup jednostavno ukazuje na to kako djeca posjeduju urođenu tzv. univerzalnu gramatiku koja upravlja ili uređuje fonološke obrasce određenog jezika, psiholingvistički model promatra fonološku vještinu kao složenu kognitivno-jezičnu vještinu. Diferenciranje sastavnica kognitivne obrade fonoloških obrazaca ima izravne praktične implikacije, jer pruža mogućnost uvida u strukturu fonološkog poremećaja, što doprinosi unapređenju dijagnostičkih i terapijskih postupaka.

\section{DEFINICIJA I RAZVOJ FONOLOŠKE VJEŠTINE}

Fonološka sposobnost definira se kao sustavna organizacija glasova u jeziku koja omogućava formiranje i razumijevanje jezičnog značenja (Hyman, 1975). Ova sposobnost omogućava čovjeku da organizira i manipulira glasovima s ciljem razvijanja razumljivog govora. Istovremeno, fonološka sposobnost predstavlja preduvjet za razvoj vještina čitanja i pisanja.

Smatra se da se elementi razvoja fonološke vještine javljaju u prvim mjesecima života (Oller, 2000) kroz glasanje novorođenčeta, što predstavlja važan okvir za dalji jezično-govorni razvoj. Sposobnost djeteta da ovlada fonološkom strukturom uvjetovana je psihofizičkim sazrijevanjem i njegovom potrebom za komunikacijom, a oblikuje se upotrebom izvora iz jezične sredine (Šmit, 1992).

Fonološki razvoj podrazumijeva razvoj oblikovanja glasova. To je proces koji teče od formiranja nejasnih, neodređenih i slučajno formiranih glasova, do izgovora jasnih, razgovjetnih i kontroliranih glasova. S razvojem perceptivnih sposobnosti broj se glasova u ranoj dječjoj dobi smanjuje, čime se sužava sposobnost proizvodnje glasova koje je dijete moglo izvesti prije nego što je ovladalo fonološkim sustavom u okviru kojega se upotrebljavaju samo određeni glasovi. Na početku jezičnog razdoblja dijete se usmjerava prema funkcionalnim jedinicama materinskog jezika, kada glasovi postaju glasovi govora. U tom razvojnom razdoblju, fonološka sposobnost omogućava da se glasovi razlikuju prema određenim akustičkim osobinama, pa $p$ više nije $t, d$, ili $b \ldots$ Dijete na taj način počinje 
proizvoditi samo one glasove koji predstavljaju dijelove fonološkog sustava jezika njegove okoline (Šmit, 1992). Međutim, svaki pojedini jezik svoj odabir glasova i glasovnih obilježja vrši iz jedinstvenog fonetskog spremnika, stvarajući na taj način vlastiti glasovni sustav. Kako svi jezici imaju različite fonološke sustave i distinkcije koje leže u osnovi svakog od njih, tako se one moraju posebno savladavati tijekom usvajanja materinskog jezika (Bugarski, 1996). Rano iskustvo u proizvodnji i imitaciji glasova pomoći će djetetu da uspostavi bolju kontrolu nad artikulacijsko-motoričkim i auditivnim feedback mehanizmima (Šmit, 1992), kao i da gradi i povezuje složene jezične sustave.

Da bi dijete bilo u stanju stvarati veze između fonetskog ulaza i odgovarajuće radnje, predmeta ili ideje, ono mora biti sposobno obraditi fonetski oblik riječi. Pojedini istraživači došli su do zaključka da je dijete u dobi od četrnaest mjeseci u stanju prepoznati greške u proizvodnji početnog dijela sličnih riječi. Nije utvrđeno percipira li dijete razlike na razini fonetskog segmenta ili na razini akustičkih razlika, ali je jasno da je dijete $u$ stanju percipirati suptilne razlike $u$ riječima (Alt $i$ Suddarth, 2012). Tako se rano uočljive fonološke vještine ogledaju kroz sposobnost prepoznavanja rime i alternacije (Qi i O'Connor, 2000; Roth i Baden, 2001), koje predstavljaju prvi pokazatelj senzitivnosti prema razumijevanju da se govor sastoji od dijelova pojedinačnih jedinica.

Dijete u dobi od dvije godine izražava sposobnost da nedosljedno, ali više nego slučajno, otkriva ponuđene rime i da od tri ponuđene riječi prepozna riječ koja se ne rimuje. Dijete u dobi od tri godine ima sposobnost prepoznati rimu između dviju riječi (Heroman i Jones, 2004; Israel, 2008). Istraživanja pokazuju da su djeca koja se uključe u obrazovni sustav sa sposobnošću prepoznavanja i proizvodnje rime i alternacije uspješnija u čitanju od djece koja nisu ovladala ovom tzv. prvom razinom fonološke svjesnosti (Ball, 1997; Bryant i sur., 1990; Goswami i Bryant, 1990; Nation i Hulme, 1997). U sljedećoj fazi dolazi do spontanog slogovnog raščlanjivanja riječi, tako da dijete u dobi od četiri godine pokazuje svijest o slogovnoj distinkciji (Adams, 1990; Snider, 1995). Poznato je da su pojedina djeca te dobi u stanju prebrojati slogove u višesložnoj riječi iako još ne poznaju zakonitost koja vlada unutar slogovnih pravila, da bi potom razvila sposobnost kategorizacije i proizvodnje riječi prema njenom inicijalnom ili finalnom glasu, što im omogućava da adekvatno ovladaju vještinom čitanja (Griffith i Olson, 1992).

Dijete $u$ dobi od pet godina ima sposobnost da spontano ili na zahtjev stvara rime i u stanju je izdvojiti prvi glas u riječima. U dobi od šest godina javlja se sposobnost fonološke analize i sinteze do pet glasova u riječi. U ovoj se dobi javlja i sposobnost fonološke elizije (uklanjanja fonološkog segmenta iz izgovorene riječi kako bi se formirala druga riječ); fonemske i slogovne kombinatorike; pravilnog i brzog imenovanja brojeva, boja, slova i objekata; dopune riječi kojoj nedostaju slogovi ili izdvojeni fonemi (fonem ili slog koji nedostaje može biti u inicijalnom, medijalnom ili finalnom položaju). Osim toga, u ovoj dobi javljaju se i segmentacija (raščlanjivanja rečenice na riječi, dijeljenja riječi na slogove i riječi na glasove); delecija (izostavljanja korijena riječi, sloga ili fonema pri stavaranju riječi) te supstitucija (sposobnost izdvajanja fonema u riječi, a zatim zamjene drugim fonemom i formiranja nove riječi) (Ball i Blachman, 1991; Ball, 1997; Heroman \& James, 2004; Goldsworthy, 1998; Justice i Schule, 2004; Snow, Burns i Griffin, 1998; Schuele i Boudreau, 2008).

Iako je razvoj fonoloških vještina dobno dokumentiran, pretpostavlja se da je razvojni redoslijed fonološke vještine (od većih prema manjim fonološkim jedinicama) manje linearan i fiksan nego što se općenito smatra. Naime, djeca mlađe predškolske dobi pokazuju posjedovanje fonemske svjesnosti i bez prethodnih izravnih uputstava. S druge strane, oko $50 \%$ trogodišnjaka u stanju je izdvojiti fonem, a četvrtina djece dobi od četiri godine može pogoditi prvi glas u riječi (Ukrainetz, Nuspl, Wilkerson i Beddes, 2011).

Navedeni podatci pokazuju da se sustav (pravila) kojim se povezuju jezične jedinice razvija postupno i po razvojnom redoslijedu koji je, uz dozvoljene varijacije u tempu, sličan za sve pripadnike određene jezične sredine. Jezični izraz postepeno se usložnjava od glasa, preko sloga i pojedinih riječi do rečenice. Razvoj glasova kod djece odvija se prema određenom redoslijedu - od artikulacijski jednostavnijih prema složenijim gla- 
sovima, u skladu s uzrastom djeteta. Prvi glasovi koji se razvijaju kod djece nisu potpuno precizni i akustički određeni. Vremenom, artikulacija glasova postaje preciznija i bliža pravilnom izgovoru.

Polazeći od pretpostavke da je osnovno načelo humane jezično-govorne komunikacije fonološki kontrast - distinkcija između diskretnih jedinica koje prenose različita gramatička, morfološka i leksička značenja (Clements i Ridouane, 2011), moglo bi se reći da upravo fonološka sposobnost predstavlja parametar razvoja ostalih jezičnih elemenata, kao i mogućnost ili nemogućnost njihovog ostvarenja. Izgleda da se upravo kroz fonološke vještine ogleda sintaktička, semantička, leksička i pragmatička sposobnost pojedinca.

Imajući u vidu sve navedene činjenice, može se reći da procjena razine fonološkog razvoja ima poseban značaj u otkrivanju posebnih jezičnih teškoća. Poznavanje faza ontogenetskog razvoja fonoloških vještina omogućava razlikovanje teškoća od tipičnih varijacija u razvoju. Istovremeno, ove spoznaje predstavljaju osnovno polazište za stvaranje programa prevencije jezičnih teškoća kod djece, uključujući i prevenciju teškoća u čitanju.

\section{FONOLOŠKI POREMEĆAJI}

\section{Povijesni osvrt}

Fonološki poremećaji svoje su terminološko određenje dobili tek prije nekoliko desetljeća, uz dugo razdoblje pokušaja razumijevanja njihove simptomatologije i njihova razlikovanja od tipično artikulacijskih poremećaja. U početku su fonološki poremećaji bili definirani kao dislalije ili funkcionalni artikulacijski poremećaji, što ukazuje na složenost problematike i nemogućnost njihova razlikovanja od naizgled sličnih oblika jezično-govornih poremećaja. Početak terminološkog razvoja i konceptualizacije fonološkog poremećaja kao specifičnog poremećaja jezika veže se uz jednu od prvih publikacija posvećenih fonološkom poremećaju kod djece (Ingram, 1976).

Bez obzira na relativno dugu povijest, pitanje fonološkog poremećaja kao zasebnog entiteta prati i većinu današnjih istraživanja u ovom području, što se može vidjeti i iz dijagnostičkih kriterija svjetskih klasifikacija (DSM IV, DSM V, ICD 10).
Pregled ovih klasifikacija pokazuje da se fonološki poremećaji svrstavaju u govorne poremećaje (Specific speech articulation disorder - ICD 10, World Health Organization, 2008), dok Američko psihijatrijsko udruženje (2010) izdvaja ovaj poremećaj kao zaseban entitet (Phonological disorder DSM 4). S druge strane, Američko psihijatrijsko udruženje (2013) fonološki poremećaj ponovo pridružuje artikulacijskom poremećaju (Speech sound disorder - DSM V), što nas ponovo vraća na početak nerazumijevanja fonologije kao čisto lingvističkog entiteta.

Poznato je da su fonološki poremećaji krajem osamdesetih godina XX. stoljeća promatrani kao dio spektra razvojnih jezičnih poremećaja (Bishop i Edmundson, 1987). S obzirom da neka djeca s fonološkim poremećajem imaju samo prateće artikulacijske teškoće, a neka i poremećaj u usvajanju jezičnih kategorija različitog stupnja, razvojni fonološki poremećaj teško se mogao terminološki odrediti. U skladu s time, razumijevanjem jezičnih poremećaja kod djece i napuštanjem nejasno definiranog termina disfazija, fonološki poremećaji zbog povezanosti s ostalim lingvističkim stajalištima nalaze svoje odredište u terminu posebne jezične teškoće.

Termin posebne jezične teškoće predstavlja veoma heterogenu skupinu odstupanja i poremećaja, pa terminološki dopušta entitetsku i združenu pojavu odstupanja i poremećaja. S obzirom na to, može se reći da je pitanje pripadnosti fonoloških poremećaja i dalje otvoreno.

Fonološki razvojni poremećaji svoje terminološko određenje dobivaju 70-ih godina XX. stoljeća. Jednu od prvih definicija fonološkog poremećaja izveo je Shriberg opisujući fonološki poremećaj kao heterogenu skupinu poremećaja koji nastaju tijekom razvojnog razdoblja, a u okviru kojeg se mogu uvrstiti i rezidualne fonološke greške koje se mogu javiti kod odraslih (Shriberg i Kwiatkowski, 1982a).

Prvi znanstveni radovi u području fonoloških poremećaja javljaju se 60 -ih godina prošlog stoljeća u području primjenjene lingvistike (Ingram, 1967; Winitz i Bellerose, 1968; Weiner, 1969), da bi idućih desetljeća u svijetu predstavljali posebno polje znanstvenih interesa logopeda, psiholo- 
ga, antropologa, neuropsihologa i neurolingvista (Alt, 2011; Ball, 1997; Bauman-Waengler, 2004; Bernhardt, 1992; Blaži, Vancaš i Prizl-Jakovac, 2000; Gathercole i Baddeley, 1990; Howell, 1989; Joanisse, 2000; Torgesen i sur., 1994; Wagner i sur., 1987). Stječe se dojam da je interes za ovu problematiku znatno veći od korpusa činjenica, međutim nedostatak suvremenih dijagnostičkih instrumenata i izostanak opsežnijih istraživanja doveli su do značajnih praznina u ovom području.

\section{Pojam i definicija}

Prvu definiciju fonoloških poremećaja predstavili su Shriberg i Kwiatkowski 1982. godine, upotrijebivši termin ,fonološki poremećaji“ za odstupanja u polju reprezentacija fonoloških pravila koje proizvode površinske forme govora - proces proizvodnje govora (Shriberg i Kwiatkowski, 1982a).

Fonološki poremećaji predstavljaju poremećaj motoričke proizvodnje, ali i jezične, reprezentacijske slike glasova, i obuhvaćaju širi termin od artikulacijskoga poremećaja (Bauman-Waengler, 2004).

Pregled literature pokazuje da se fonološki poremećaji promatraju kao kognitivno-jezični poremećaji koji su rezultat odstupanja u govornoj percepciji i/ili nespecifičnim fonološkim reprezentacijama (Bernthal i Bankson, 2004). Pored toga, fonološki poremećaji definiraju se i kao teškoće u govorno-glasovnoj proizvodnji koje čine govor teško razumljivim. Poremećaj se odnosi na teškoće u učenju i organiziranju svih glasova potrebnih za razumljiv govor, pravilno pisanje i čitanje riječi (Webster, Plante i Couvillion, 1997).

Općenito je prihvaćen stav kako fonološki poremećaji utječu na govornikovu proizvodnju i/ ili mentalne reprezentacije glasova određenog jezika (Bernthal i Bankson, 1993; Edwards i Shriberg, 1983; Fey, 1992; Grunwell, 1981; Hoffman i Daniloff, 1990; Ingram, 1989; Leonard, 1973; Shriberg i Kwiatkowski, 1982b). U govornikovoj proizvodnji, fonološki poremećaj može odražavati nesposobnost da se artikuliraju govorni glasovi, pri čemu se komunikacijske teškoće mogu odnositi na motoričku komponentu. Ovaj tip poremećaja opisuje se kao fonetski (artikulacijski), budući da teškoće leže u načinu na koji se glasovi artikuliraju
(Dinnsen, 1984; Hoffman, Schuckers i Daniloff, 1989; Stoel-Gammon, 1985).

Fonološki poremećaj može odražavati i način na koji je informacija o glasovima govora sačuvana $i$ predstavljena u mentalnom leksikonu ili način na koji je ta informacija kognitivno dostupna odnosno moguća za prizivanje (Bernhardt, 1992; Blaži i sur., 2000; Dean, Howell, Waters i Reid, 1995; Stackhouse i Wells, 1993). U tom slučaju komunikacijske teškoće mogu imati jezičnu ili kognitivnu osnovu. Poremećaji ovog tipa nazivaju se fonemskima (fonološkima), budući da teškoće mogu uključivati način na koji se glasovi upotrebljavaju za označavanje razlika između riječi (Dinnsen, 1984; Elbert, 1992).

Tipovi fonoloških poremećaja (fonetski i fonemski) međusobno se ne isključuju. Tako fonološki poremećaji mogu imati široki utjecaj na djetetovu artikulaciju (proizvodnju) i unutrašnje znanje (kompetenciju) o sustavu glasova određenog jezika (Kamhi, 1992). Čini se da je reducirana kompetencija za određen broj glasova jedna od prvih karakteristika koja upućuje na fonološki poremećaj, ali je ona istovremeno nepotpuna za razumijevanje suvremenog koncepta fonološkog razumijevanja, organizacije i proizvodnje (Shriberg i Kwiatkowski, 1982b).

U pregledu međunarodne literature pronalazimo opis fonoloških poremećaja kod djece s mnogobrojnim greškama u proizvodnji glasova (eng. speech sound disorder), koje ugrožavaju razumljivost govora. Fonološki poremećaji prepoznaju se kroz teškoće u razumijevanju i produkciji rime (svjesnost o rimi), stapanju i raščlambi slogova u riječi (svjesnost o slogovima), analizi i sintezi glasova u riječi, raščlambi rečenice na riječi (svjesnost o riječi), prepoznavanju slova, fonološkom pamćenju i brzom imenovanju.

Dodatno, opisuju se i poremećaji fonoloških vještina kod djece s posebnim jezičnim teškoćama. U literaturi se navodi da se kod $56 \%$ djece s posebnim jezičnim teškoćama javljaju poremećaji fonološkog aspekta (Shriberg, Tomblin i McSweeny, 1999). Rezultati pojedinih istraživanja, međutim, ukazuju na razliku između djece s izdvojenim fonološkim poremećajima i djece s posebnim jezičnim teškoćama koja imaju fonološke teškoće. Prema 
tim nalazima djeca s posebnim jezičnim teškoćama imaju višestruke govorne-jezične teškoće, iako razlike u govornoj produkciji nisu bile značajne. Također je utvrđeno da se govorna proizvodnja kod izdvojenih fonoloških poremećaja normalizira do polaska u školu, dok kod $60 \%$ djece s posebnim jezičnim teškoćama ona ostaje narušena. Kada su u pitanju mjere neverbalne inteligencije, pokazalo se da je rezultat djece s posebnim jezičnim teškoćama niži $(98,8)$ od djece s izdvojenim fonološkim poremećajima $(115,9)$. Mjere fonološke svjesnosti pokazale su da djeca s posebnim jezičnim teškoćama imaju veće teškoće, koje kasnije zatim utječu na razvoj vještina čitanja i pisanja (Lewis, Freebairn i Taylor, 2002).

Globalno promatrano, fonološki poremećaji odražavaju se kroz tri područja (Wagner i Torgesen, 1987): fonološku svjesnost (Mann iLiberman, 1984), prizivanje fonoloških kodova iz dugoročnog pamćenja - brzo automatsko imenovanje (Bowers i Swanson, 1991) i verbalno kratkoročno pamćenje (Catts, 1989; Mann i Liberman, 1984).

Da razvojni fonološki poremećaj predstavlja značajan klinički entitet pokazuju i podatci o posljedicama ovog poremećaja na usvajanje školskih vještina. Tako je još osamdesetih godina XX. stoljeća pokazana povezanost između fonološke vještine i teškoća u učenju čitanja i pisanja. Veći broj prediktivnih studija pokazuje da je nerazumijevanje fonološke strukture jezika (fonološke svijesti) snažan prediktivni čimbenik kasnijih teškoća u čitanju. Tako je Catts sa suradnicima longitudinalno obradio 604 mlađa ispitanika s teškoćama u čitanju, od kojih je preko $70 \%$ u anamnezi imalo jezične teškoće i poremećaje koji su uključivali teškoće u razvoju fonološke svjesnosti i teškoće u artikulaciji tijekom predškolskog razdoblja (Catts, Fey, Zhang i Tomblin, 1999). Mjere koje odražavaju fonološke procese relevantne za usvajanje čitanja sadrže vrlo različite zadatke, poput fonološke/fonemske svjesnosti, fonološkog pamćenja, fonološkog imenovanja te imenovanja slova (Ivšac Pavliša i Lenček, 2011).

Posljedice fonoloških poremećaja detaljno su opisane i u novijoj literaturi. Kako fonološke vještine predstavljaju važnu osnovu čitačkih i akademskih vještina, pokazano je da djeca s ograničenjima u fonološkoj obradi postaju loši čitači (McDowell,
Lonigan i Goldstein, 2007). Prema hipotezi ograničenja fonološke obrade (Shankweilera i Craina, 1986), loši čitači nisu u mogućnosti stvoriti smislenu reprezentaciju teksta, zbog teškoća u fonološkom razvoju. Teškoće se mogu manifestirati problemima u razvoju fonološke svjesnosti ili problemima u obradi i zadržavanju fonoloških informacija, odnosno fonološkom pamćenju. Pretpostavlja se da teškoće u pamćenju kod loših čitača nisu povezane s kontrolnom komponentom radnog pamćenja, već proizlaze iz ograničenog neposrednog, odnosno kratkoročnog pamćenja i nepotpunog shvaćanja da riječi imaju fonološku strukturu koja je povezana s načinom na koji se neka riječ piše. Smatra se da deficiti koji uključuju fonološke komponente (nižeg stupnja) ostavljaju posljedice na više razina, te da većina jezičnih problema na različitim razinama proizlazi iz zajedničkog izvora - problema u fonološkoj obradi.

U pregledu literature prikazano je i diferenciranje fonoloških poremećaja od čistih artikulacijskih teškoća. Djeca s artikulacijskim poremećajima izražavaju nemogućnosti ili nepravilnosti u izgovoru pojedinih glasova u vidu omisija, sustavnih supstitucija i distorzija, koje odražavaju fonetska odstupanja. Međutim, u sklopu kliničke manifestacije posebnih jezičnih teškoća, fonetska odstupanja praćena su i greškama tipa adicije, inverzije, haplologije, nesustavne supstitucije i omisije formiranih i distorziranih glasova, što predstavlja deficit u fonološkom razvoju (Milošević i Vuković, 2010).

Podatci iz literature pokazuju da među znanstvenicima još uvijek postoje neslaganja u pogledu definiranja fonoloških teškoća, iako ovo pitanje veoma dugo zaokuplja pažnju stručnjaka. Dok neki autori fonološke teškoće promatraju kao oštećenje procesa proizvodnje glasova (Shriberg i Kwiatkowski, 1982a), drugi u definiranju, pored teškoća u artikulaciji, uključuju i teškoće jezične prirode u smislu poremećaja reprezentacijske slike glasova (Bauman-Waengler, 2004). Potpuniju definiciju fonoloških teškoća dali su Bernthal i Bankson (2004), koji ovaj poremećaj promatraju $\mathrm{s}$ kognitivno-lingvističkog stajališta, ističući da se u njegovoj osnovi nalaze odstupanja u govornoj percepciji i/ili nespecifičnim fonološkim reprezentacijama. Kognitivno-lingvističkom pristupu shvaćanja fonoloških teškoća pridonosi i gledište Wagnera 
i Torgesena (1987), prema kojem fonološke teškoće odražavaju oštećenje fonološke svjesnosti, fonološkog pamćenja i brzog imenovanja riječi, što ukazuje na metalingivstičke nedostatke, teškoće u prizivanju fonoloških kodova iz dugoročnog pamćenja i teškoće u radnoj memoriji.

S obzirom na navedne činjenice, mišljenja smo kako fonološke teškoće predstavljaju zaseban klinički entitet, koji predstavlja oštećenje sposobnosti fonološke obrade jezičnih elemenata. Fonološki nedostatci obično su praćeni odstupanjima u artikulaciji glasova za koja se može reći da predstavljaju prije komorbiditet, nego strukturnu komponentu razvojnog fonološkog poremećaja. Činjenica je da prisustvo fonološkog poremećaja kod djece može utjecati na razvoj leksičkih i morfosintaksičkih vještina, što ostavlja dojam šireg jezičnog poremećaja, poznatog pod nazivom posebne jezične teškoće. Stoga je veoma važno utvrditi razinu fonološkog nedostatka i njegov mogući utjecaj na ostala stajališta jezične strukture, kao bi se razumjela sama priroda fonološkog nedostatka.

Etiološka istraživanja razvojnih fonoloških poremećaja proučavaju fonološke posljedice kao biološka i okolinska ograničenja u različitim razdobljima rasta i razvoja. Iako teškoće govorno-slušnih mehanizama, pretežno slušno-perceptivnih, ali i kognitivno-lingvističkih i psiho-socijalnih mogu biti dovoljan razlog za pojavu fonoloških poremećaja, još uvijek ne postoje studije koje jasno pronalaze vezu između fonoloških poremećaja i specifičnih etioloških faktora. Bez obzira na uzrok, interpretiranje fonološkog poremećaja mora se bazirati na razumijevanju same strukture sposobnosti fonološke obrade i procesa razvoja fonoloških vještina.

\section{ZAKLJUČAK}

Cilj ovog rada je bio da se na osnovu pregleda i analize dostupne literature doprinese bližem određivanju i interpteciji fonološkog poremećaja. $\mathrm{Na}$ osnovu iznijetih podataka može se zaključiti da poznavanje definicije i razvojnog slijeda usvajanja fonološke vještine predstavlja polazni parametar u određivanju fonološkog poremećaja. Tako su, na primjer, odsutnost svjesnosti o rimi, slogovima, fonemima i riječima, odsutnost sposobnosti fonološke elizije, glasovne analize i sinteze i kombinatorike glasovima u dobi prije polaska u školu, znak teškoća u fonološkom razvoju. Pored posjedovanja jasnog pojma fonološke vještine i poznavanja razvoja fonološke strukture, za otkrivanje i interpretaciju fonološkog poremećaja neophodno je znanje o univerzalnostima fonološkog razvoja i fonoloških specifičnosti svakog jezika, posebno u području jezične ortografije. Poznavanje suvremenih pristupa i modela u shvaćanju fonološke vještine i fonološke obrade omogućava pravovremeno prepoznavanje fonološkog poremećaja i prevenciju njegovih posljedica na usvajanje akademskih vještina.

Znanstvena istraživanja u logopediji i psiholingvistici posljednjih godina doprinijela su potpunijem sagledavanju pojma fonološke vještine $i$ utvrđivanju normativa fonološkog razvoja, čime je omogućeno konstruiranje mjernih instrumenata za ispitivanje i dijagnostiku fonološkog poremećaja. $\mathrm{Na}$ taj način koncipirani mjerni instrumenti imaju neprocjenjiv značaj u planiranju logopedskih, edukacijskih i rehabilitacijskih postupaka kod djece s fonološkim poremećajima. 


\section{LITERATURA}

Adams, M.J. (1990): Beginning to read: Thinking and learning about print. Cambridge, MA: Bolt, Beranek and Newman, Inc.

Alt, M. (2011): Phonological working memory impairments in children with specific language impairment: Where does the problem lie? Journal of Communication Disorders, 44, 2, 173-185. doi: 10.1016/j.jcomdis.2010.09.003

Alt, M., \& Suddarth, R. (2012): Learning novel words: Detail and vulnerability of initial representations for children with specific language impairment and typically developing peers. Journal of Communication Disorders, 45, 84-97.

American Psychiatric Association. (2000): Diagnostic and statistical manual of mental disorders (4th ed., text rev.). Washington, DC: Author.

American Psychiatric Association. (2013): Diagnostic and statistical manual of mental disorders (5th ed.). Arlington, VA: American Psychiatric Publishing.

Ball, E.W., \& Blachman, B.A. (1991): Does phoneme awareness training in kindergarten make a difference in early word recognition and developmental spelling? Reading Research Quarterly, 26, 49-66.

Ball, E.W. (1997): Phonological awareness: Implications for whole language and emergent literacy programs. Topics in Language Disorders, 17, 14-26.

Barlow A. J., \& Gierut A. J. (1999): Optimality Theory in Phonological Acquisition. Journal of Speech, Language, and Hearing Research, 42, 1482-1498.

Bauman-Waengler, J. (2004): Articulatory and Phonological Impairments: A Clinical Focus (2cd ed). Boston: Pearson.

Bernhardt, B. (1992): The application of nonlinear phonological theory to intervention with one phonologically disordered child. Clinical Linguistics \& Phonetics, 6, 283-316.

Bernthal, J. E., \& Bankson, N. W. (1993): Articulation and phonological disorders (3rd ed.). Englewood Cliffs, NJ: Prentice Hall.

Bishop, D.V.M., \& Edmundson, A. (1987): Language Impaired 4 year olds: Distinguishing transient from persistent impairment. Journal of Speech and Hearing Disorders, 52, 156-173.

Blaži, D., Vancaš, M., \& Prizl-Jakovac, T. (2000): Fonološki poremećaji i fonemska diskriminacija u predškolske djece. Hrvatska revija za rehabilitacijska istraživanja, 36,2, 165-169.

Bowers, P. G., \& Swanson, L. B. (1991): Naming speed deficits in reading disability: Multiple measures of a singular process. Journal of Experimental Child Psychology, 51, 195-219.

Bryant, P.E., MacLean, M., Bradley, L.L., \& Crossland, J. (1990): Rhyme and alliteration, phoneme detection, and learning to read. Developmental Psychology, 26, 429-438.

Bugarski, R. (1996): Uvod u opštu lingvistiku. Beograd: Čigoja štampa.

Catts, H. W. (1989): Phonological processing deficits and reading disabilities. In A. G. Kahmi \& H.W. Catts (Eds.): Reading disabilities: A developmental language perspective (pp. 101-132). Boston, MA: Littel Brown.

Catts, H. W., Fey, M.E., Zhang, X., \& Tomblin, J. B. (1999): Language basis of reading and reading disabilities: Evidence from a longitudinal investigation. Scientific Studies of Reading, 3, 331-361.

Clements, N., \& Ridouane, R. (2011): Where Do Phonological Features Come From? Cognitive, Physical And Developmental Bases Of Distinctive Speech Categories. Amsterdam, NLD: John Benjamins Publishing Company.

Chomsky, N. (1965): Aspects of the theory of syntax. Cambridge, MA: MIT Press.

Chomsky, N., \& Halle, M. (1968): The Sound Pattern of English. New York: Harper and Row.

Dean, E. C., Howell, J., Waters, D., \& Reid, J. (1995): Metaphon: A metalinguistic approach to the treatment of phonological disorder in children. Clinical Linguistics \& Phonetics, 9, 1-19. 
Dinnsen, D. A. (1984): Methods and empirical issues in analyzing functional misarticulation. In: M. Elbert, D. A. Dinnsen, \& G. Weismer (Eds.): Phonological theory and the misarticulating child (ASHA Monographs No. 22) (pp.5-17) Rockville, MD: ASHA.

Edwards, M. L., \& Shriberg, L. D. (1983): Phonology: Applications in Communicative Disorders. San Diego, CA: College-Hill.

Elbert, M. (1992): Consideration of error types: A response to Fey. Language, Speech, and Hearing Services in Schools, 23, 241-246.

Fey, M. E. (1992): Articulation and phonology: Inextricable constructs in speech pathology. Language, Speech, and Hearing Services in the Schools, 23, 225-232.

Gathercole, S.E., \& Baddeley, A.D. (1990): Phonological memory deficits in language-disordered children: Is there a causal connection? Journal of Memory and Language, 29, 336-360.

Goldsworthy, C. (1998): Sourcebook of phonological awareness training: Children's classic Literature. San Diego, CA: Singular Publishing.

Goswami, U., \& Bryant, P. (1990): Phonological skills and learning to read. East Sussex. UK: Lawrence Erlbaum Associates, Ltd.

Griffith, P.L., \& Olson, M.W. (1992): Phonemic awareness helps beginning readers break the code. The Reading Teacher, 45, 516-523.

Grunwell, P. (1981): The nature of phonological disability in children. New York: Academic.

Heroman, C., \& Jones, C. (2004): Literacy: The creative curriculum approach. Washington, D.C.: Teaching Strategies, Inc.

Hyman, L. (1975): Phonology: Theory and analysis. New York: Holt, Rinehart, \& Winston.

Hockett, C. (1955): A Manual of Phonology. Baltimore: Waverly Press.

Hoffman, P., Schuckers, G., \& Daniloff, R. (1989): Children's phonetic disorders: Theory and treatment. Austin, TX: Pro-Ed.

Hoffman, P. R., \& Daniloff, R. G. (1990): Evolving views of children's disordered speech sound production from motoric to phonological. Journal of Speech-Language Pathology and Audiology, 14, 13-22.

Howell., J (1989): The metalinguistic awareness of phonologically disordered and normally developing children: a comparative study. Thesis/dissertation. University of Newcastle upon Tyne.

Ingram, D. (1976): Phonological disability in children. London: Edward Arnold.

Ingram, D. (1989): Phonological disability in children (2nd ed.). San Diego, CA: Singular.

Ivić, M. (1970): Pravci u lingvistici. Ljubljana: Državna založba Slovenije.

Ivšac Pavliša, J., \& Lenček, M. (2011): Fonološke vještine i fonološko pamćenje: neke razlike između djece urednoga jezičnoga razvoja, djece s perinatalnim oštećenjem mozga i djece s posebnim jezičnim teškoćama kao temeljni prediktor čitanja. Hrvatska revija za rehabilitacijska istraživanja, 47(1), 1-16.

Israel, S.E. (2008): Early reading first and beyond: A guide to building early literacy skills. Thousand Oaks, CA: Corwin Press.

Jakobson, R., \& Halle, M. (1988): Temelji jezika. Zagreb: Globus.

Joanisse, M.F. (2000): Connectionist Phonology, Ph.D. Dissertation, University of Southern California.

Justice, L.M., \& Schule, C.M. (2004): Phonological Awareness: Description, Assessment, and Intervention. In J. Bernthal \& N. Bankston, Articulation and Phonological Disorders, 5th ed. Boston: Allyn \& Bacon.

Kamhi, A. G. (1992): The need for a broad-based model of phonological disorders. Language, Speech and Hearing Services in Schools, 23, 261-268. 
Leonard, L. B. (1973): The nature of disordered articulation. Journal of Speech and Hearing Disorders, 38, 156-161.

Lewis, B., Freebairn, L., \& Taylor, H.G. (2002): Correlates of spelling abilities in children with early speech sound disorders. Reading and Writing: An Interdisciplinary Journal 15, 389-407.

Mann, V. A., \& Liberman, I. Y. (1984): Phonological awareness and verbal short-term memory: Can they presage early reading problems? Journal of Learning Disabilities, 17, 592-599.

McDowell, K., Lonigan, C., \& Goldstein, H. (2007): Relations Among Socioeconomic Status, Age, and Predictors of Phonological Awareness. Journal of Speech, Language, and Hearing Research, 50, 1079-1092.

Milošević, N., \& Vuković M. (2010): Articulation-Phonological Deficits in Children with Specific Developmental Language Imapirment. In: Special education and Rehabilitation, Science and/or practice, Thematic collection of papers (edited by Nedovic, G., Rapaic, D., Marinkovic, D.), Sombor, Society of Special Educators and Rehabilitators. 437-454.

Nation, K., \& Hulme, C. (1997): Phonemic segmentation, not onset-rime segmentation, Predicts early reading and spelling skills. Reading Research Quarterly, 32, 154-167.

Oller, D.K. (2000): The grounding of vocal and gestural development in biology and experience: physical foundantions for speech and sing language. In Oller, D.K (ed.) The emergence of the speech capacity. Lawrance Erlbaum associates, 112-131.

Qi, S., \& O'Connor, R. (2000): Comparison of phonological training procedures in kindergarten classrooms. The Journal of Educational Research, 93, 226-233.

Roth, F.P., \& Baden, B. (2001): Investing in emergent literacy intervention: A key role for speech-language pathologists. Seminars in Speech and Language, 22, 163-173.

Schuele, C.M., \& Boudreau, D. (2008): Phonological awareness intervention: Beyond the Basics. Language, Speech, and Hearing in Schools, 39, 3-20.

Shankweiler, D., \& Crain, S. (1986): Language mechanisms and reading disorder: A modular approach. Cognition, 24, 139-168.

Shriberg, L. D., \& Kwiatkowski, J. (1982): Phonological disorders I: A diagnostic classification system. Journal of Speech and Hearing Disorders, 47, 226-241. (a)

Shriberg, L. D., \& Kwiatkowski, J. (1982): Phonological disorders III: A procedure for assessing severity of involvement. Journal of Speech and Hearing Disorders, 47, 256-270. (b)

Shriberg, L., Tomblin, J., \& McSweeny, J.(1999): Prevalence of speech delay in 6-year-old children and comorbidity with language impairment. Journal of Speech, Language, and Hearing Research, 42, 1461-1481.

Snider, V. (1995): A primer on phonemic awareness: What it is, why it's important, and how to teach it. School Psychology Review, 24, 443-455.

Snow, C.E., Burns, M.S., \& Griffin, P. (Eds.). (1998): Preventing reading difficulties in young children. Washington, DC: National Academy Press.

Stackhouse, J., \& Wells, B. (1993): Psycholinguistic assessment of developmental speech disorders. European Journal of Disorders of Communication, 28, 331-348.

Stoel-Gammon, C. (1985): Phonetic inventories, 15-22 months: A longitudinal study. Journal of Speech and Hearing Research, 28, 505-512.

Šmit, V.H.O. (1992): Razvoj deteta - biološki, kulturološki i vaspitni okvir proučavanja. Beograd: Piccadilly Books.

Torgesen, J. K., Wagner, R. K., \& Rashotte, C. A. (1994): Longitudinal studies of phonological processing and reading. Journal of Learning Disabilities, 27, 276-286.

Ukrainetz, T., Nuspl, J., Wilkerson, K., \& Beddes, S. (2011): The effects of syllable instruction on phonemic awareness in preschoolers. Early Childhood Research Quarterly, 26, 50-60. 
Wagner, R. K., Balthazor, M., Hurley, S., Morgan, S., Rashotte, C., Shaner, R., Simmons, K., \& Stage, S. (1987): The nature of prereaders' phonological processing abilities. Cognitive Development, 2, 355-373.

Wagner, R. K., \& Torgesen, J.K., (1987): The Nature of Phonological Processing and Its Causal Role in the Acquisition of Reading Skills. Psychological Bulletin, 101(2), 192-212.

Wagner, R. K., Torgesen, J. K., Rashotte, C. A., Hecht, S. A., Barker, T. A., Burgess, S. R., Donahue, J., \& Garon, T. (1997): Changing relations between phonological processing abilities and word-level reading as children develop from beginning to skilled readers: A 5-year longitudinal study. Developmental Psychology, 33, 468-479.

Weiner, S. P. (1969): The Perceptual Level Functioning of Dysphasic Children. Cortex, 5(4), 440-457.

Webster, P.E., Plante, A.S., \& Couvillion, L.M. (1997): Phonologic impairment and prereading: Update on a longitudinal study. Journal of Learning Disabilities, 30, 365-375.

Winitz, H., \& Bellerose, B. (1968): Relation between sound discrimination and sound learning. Journal of Communication Disorders, 1(3),215-235.

World Health Organization. (2008): ICD-10: International statistical classification of diseases and related health problems (10th Rev. ed.). New York, NY: Author.

\section{PHONOLOGICAL ABILITY AS A DETERMINANT FOR DEFINING AND INTERPRETING PHONOLOGICAL DISORDERS}

\footnotetext{
Abstract: This study gives an overview of different approaches to defining and analyzing the development of phonological abilities for the purpose of determining and understanding the nature of developmental phonological disorders. Earlier studies have observed developmental phonological disorders from the aspect of how linguistics understands phonology. However, some newer studies show that the focus has now shifted to overall linguistic behavior and linguistic functioning. The purpose of this study was to make a conceptual framework for both phonological abilities and disorders, based on considerations about the development of linguistic and psycholinguistic theories. Key elements for defining a phonological ability and detecting a phonological disorder have been outlined. The study ends with the conclusion that the two main determinants for recognizing and defining a phonological disorder in children are the perception of the notion of phonological ability and knowledge about the main and specific characteristics of phonological subsystems.
}

Keywords: phonological development, phonological ability, phonological disorders, reading disability 